\title{
AGE AND THE QUALITY OF WORK: \\ THE CASE OF MODERN \\ AMERICAN PAINTERS
}

David W. Galenson

Bruce A. Weinberg

Working Paper 7122

http://www.nber.org/papers/w7122

\section{NATIONAL BUREAU OF ECONOMIC RESEARCH \\ 1050 Massachusetts Avenue \\ Cambridge, MA 02138 \\ May 1999}

The views expressed herein are those of the authors and do not necessarily reflect the views of the National Bureau of Economic Research.

(c) 1999 by David W. Galenson and Bruce A. Weinberg. All rights reserved. Short sections of text, not to exceed two paragraphs, may be quoted without explicit permission provided that full credit, including (c) notice, is given to the source. 
Age and the Quality of Work:

The Case of Modern American Painters

David W. Galenson and Bruce A. Weinberg

NBER Working Paper No. 7122

May 1999

JEL No. J24

\begin{abstract}
$\underline{\text { ABSTRACT }}$
Psychologists have found that the age at which successful practitioners typically do their best work varies across professions, but they have not considered whether these peak ages change over time, as economic models suggest they might. Using auction records, we estimate the relationship between artists' ages and the value of their paintings for two successive cohorts of modern American painters. We find that a substantial decline occurred over time in the age at which these artists produced their most valuable - and most important - work, and argue that this was caused by a shift in the nature of the demand for modern art during the 1950s.
\end{abstract}

David W. Galenson

Department of Economics

University of Chicago

1126 E. 59th Street

Chicago, IL 60637

and NBER

sogrodow@midway.uchicago.edu
Bruce A. Weinberg

Department of Economics

Ohio State University

1945 North High Street

Columbus, $\mathrm{OH} 43210$

weinberg.27@osu.edu 


\section{$\underline{\text { Introduction }}$}

The age at which successful practitioners typically do their best work is known to vary across professions. Studies by psychologists have shown that mathematicians, physicists, and poets typically make their most important contributions at younger ages than do astronomers, biologists, and novelists. ${ }^{1}$ Psychologists consider these differences to be a function of the rates at which creative ideations can be produced and elaborated: they believe that both of these processes are more rapid in disciplines that deal with abstract conceptual entities than in those whose central ideas are more complex and concrete. ${ }^{2}$ The psychologists' empirical studies have been based on the assumption that the typical peak age for creativity in a profession is invariant over time, or changes only gradually. ${ }^{3}$ Yet economists have pointed to a variety of factors that can potentially produce rapid changes in the relationship between age and productivity in a given activity. ${ }^{4}$ This paper presents a case study of a profession in which a change in the criteria for quality produced a dramatic change in the age at which successful practitioners executed their best work.

The profession considered here is modern American painting. We use the records of paintings sold at auctions since 1980 to estimate the relationship between artists' ages and the value of their work for two successive birth cohorts of successful modern artists. The particular artists studied include the most important American painters born in the first 40 years of this century. Our argument is that a shift in the nature of the demand for fine art occurred during the early 1950s, and that this shift produced a decline in the age at which successful contemporary painters typically produced their best work. The timing of the shift leads us to divide the artists studied into those born during 1900-20, who entered the profession before the shift occurred, and those born during 1921-40, who entered the profession during or after the shift in demand. This 
shift occurred in the American market, so the sample of artists to be studied consists of painters born in these periods who worked in the US. Since our interest is in successful artists, the sample was defined to be all such painters of sufficient stature to have had at least one painting reproduced in three or more of six leading surveys of art history. ${ }^{5}$ These artists are listed in Table 1.

The sample itself is of some interest, for there are several clear contrasts between the two birth cohorts. One is the difference in size, as the second contains more than twice as many painters as the first. Another concerns the degree of heterogeneity: whereas ten of the fifteen painters of the first cohort are identified with a single type of painting, Abstract Expressionism, the second cohort contains members of many different movements, including Color-field Painting, Op Art, Pop Art, Minimal Art, Conceptual Art, and others. Both of these differences - the increasing number of successful American artists, and their increasing stylistic diversity - may be results of the increase in the demand for contemporary American art that is the central change driving the hypothesis to be considered in this paper.

\section{Changes in Artists' Careers: A Hypothesis}

As noted above, the earlier of the two cohorts of artists considered here is dominated by the Abstract Expressionists. This was an informal group that originated in New York during the 1930s, when most of its members were employed by the WPA. These artists entered a profession in which there was little immediate demand for their work. Few galleries sold the work of American painters during the 1920s, and this changed little during the Depression and World War

II. One of the Abstract Expressionists, Adolph Gottlieb, later recalled that "By the age of 18 [in 
1921], I clearly understood that the artist in our society can not expect to make a living from art." ${ }^{\prime 6}$ These artists were nonetheless committed to their profession, and their development was greatly affected by the arrival of a number of leading European modern artists in New York during World War II. One of the most prominent of the Americans, Jackson Pollock, stated in 1944: "I accept the fact that the important painting of the last hundred years was done in France ... Thus the fact that good European moderns are now here is very important, for they bring with them an understanding of the problems of modern painting."

During the late 1940s, Pollock and his colleagues blended the approach of the European Surrealists with a variety of American influences to develop a genuinely new art. In a famous essay, the critic Harold Rosenberg described this new art as "action painting": "What was to go on the canvas was not a picture but an event. The painter no longer approached his easel with an image in his mind; he went up to it with material in his hand to do something to that other piece of material in front of him. The image would be the result of this encounter." ${ }^{\prime 8}$ Abstract Expressionism was an art in which the touch of the individual painter was central. From both American and European teachers, the Abstract Expressionists had learned the skills of the modern artists who had proceeded them, and had found them inadequate for their purposes. Believing in Pollock's words - that "new needs need new techniques," they experimented with new kinds of paint, new ways of applying paint to canvas, new surface textures, new all-over compositions, and new visual images. ${ }^{9}$ Although these artists came to be considered as a group - by themselves as well as by critics - they had little in common except their dissatisfaction with existing methods of painting. ${ }^{10}$ The work of each came to be known for a distinctive idiom, made up of particular expressive gestures and visual effects that recurred throughout his paintings. 
By 1950 the Abstract Expressionists, the youngest of whom was 35, had all gone through an extended period of experimentation in developing their personal styles. They had done this in the absence of any significant demand for their work: thus in 1949 their most eloquent advocate, the critic Clement Greenberg, bemoaned the fact that "these individuals must still waste valuable energy in the effort to survive as working artists in the face of a public whose indifference consigns them to neglect and poverty," and complained that "it remains as difficult as ever for a young American painter or sculptor working in an advanced mode to win real attention in New York." 11 This situation changed greatly during the "50s. The persuasive essays of Greenberg began to have an impact, and the demand for the work of Pollock and others began to grow. ${ }^{12}$ The small number of pioneering galleries devoted to selling contemporary American art also began to grow. ${ }^{13}$ When young artists of the second cohort considered here arrived in New York to become professional painters, they consequently found a very different situation than had their predecessors. As William Rubin, director of the Museum of Modern Art, later wrote, "By 1958, when [Frank] Stella came to New York, the art-buying public had become convinced that Americans could produce major painting, worthy of comparison with the best of earlier European modern art. And it was now clear that this work could be sold at prices that made an artists's profession economically feasible." ${ }^{14}$

Greenberg's promotion and the increasing number of outlets for American paintings did not simply increase the demand for contemporary art; they also changed the nature of that demand. The Abstract Expressionists strongly believed that the importance of their art lay in its subject matter. Although their work was non-representational, they insisted that the purpose of their imagery was to communicate ideas and feelings. Thus for example in 1943 Adolph Gottlieb, 
and Mark Rothko jointly declared: "There is no such thing as good painting about nothing. We assert that the subject is crucial." $" 15$ Yet Greenberg disagreed. He dismissed the "symbolical or 'metaphysical' content" of the Abstract Expressionists' work as "half-baked."16 In his view their contribution lay entirely in the formal properties of their paintings, in their innovative use of "line, color, and form," without reference to subject matter. ${ }^{17}$

Greenberg's formalist approach had little effect on Pollock and his contemporaries, who were already mature artists when Greenberg began to write about their work, but it had a great impact on their successors. Young artists impressed by Greenberg's analysis of the success of the new American painting came to "conceive of stylistic change in terms of the decisions of individual artists to engage with particular formal problems thrown up by the art of the recent past," in the words of Michael Fried, a young critic and disciple of Greenberg, in $1965 .{ }^{18}$ A critic who disapproved of Greenberg's approach remarked in 1968 on the pervasiveness of its influence, "how often recent American Abstract painting is defined and described almost exclusively in terms of internal problem-solving. As though the strength of a particular artist expressed itself only in his choice to conform with a set of existent professional needs and his inventiveness in producing the answers." The critic, Leo Steinberg, complained that "The dominant formalist critics today tend to treat modern painting as an evolving technology wherein at any one moment specific tasks require solution ... The artist as engineer and research technician becomes important insofar as he comes up with solutions to the right problem."19

Henry Geldzahler, appointed in 1966 as the first curator of contemporary art at New York's Metropolitan Museum, argued that growing attention from the media and the increasing importance of the gallery system also contributed to an increased demand for innovation in 
painting. National magazines began to take note of the rise of Abstract Expressionism at the end of the 1940s, and their new interest in American painting meant that their "concern for immediacy" focused attention exclusively on the "novel moments" in artists' careers. Galleries would hold shows of the work of each of their associated artists at regular intervals, and dealers, faced with "an audience overeager to spot trends, rising reputations, and falls from favor," wanted to assure that audience that their current shows contained new and improved work. ${ }^{20}$ In view of the importance of innovation, Geldzahler compared the recent development of modern art to "a group research project, the way pure mathematics might be."21

The impact of Greenberg's criticism and of the expanding gallery system produced a new regime in modern American art. In 1968 Greenberg himself surveyed the results, and concluded that "Until the middle of the last century innovation in Western art had not had to be startling or upsetting; since then ... it has had to be that. And now in the 60s it is as though everybody had finally ... caught on not only to the necessity of innovation, but also to the necessity - or seeming necessity - of advertising innovation by making it startling and spectacular.” Producing conspicuous innovations had become a preoccupation: "Today everybody innovates. Deliberately, methodically. And the innovations are deliberately and methodically made startling." ${ }^{22}$ Similarly, Geldzahler recalled "in the late 1950s being shocked to hear painters, who believed in the primacy of de Kooning's position and who admired him, wondering aloud whether next year's show would repeat his success, whether he could consolidate his lead not by painting a beautiful show but by changing in an unexpected and unpredictable way." Geldzahler believed that younger artists understood how to respond to the pressure of the demand for innovation because they had learned from the experience of their elders: "the younger generation has had the 
example of the successful Abstract Expressionists before them and are much less vulnerable than were the artists in the fifties, the first to sit on this particular griddle."23

The growing demand for innovations changed the nature of modern art. Whereas Abstract Expressionism had developed gradually through trial-and-error experimentation, the trademark touch of its practitioners was now replaced by a conceptual approach that valued new ideas above technique. Among the most successful members of the later cohort was Frank Stella. Michael Fried, a college friend, later recalled that when he and Stella were students at Princeton, "Greenberg was the only art critic we valued and wanted to read." ${ }^{24}$ In 1960, two years after graduating from college, Stella had a one-man show at one of New York's leading galleries. Fried described these paintings, "in which parallel stripes of black paint, each roughly $2 \frac{1}{2}$ inches wide, echo and reecho the rectangular shape of the picture support until the entire canvas is filled," as "a significant advance on the work of the Cubists or even Mondrian," because they embodied "more consistent solutions to a particular formal problem." 25 Stella insisted that his work had no symbolic meaning: dismissing "people who want to retain the old values in painting the humanistic values that they always find on the canvas," he stated that "My painting is based on the fact that only what can be seen there is there ... What you see is what you see." 26

Some artists of the later cohort devised new methods of producing art that avoided any possibility of the visible gestures that characterized Abstract Expressionism. In 1967, Sol LeWitt declared that "In conceptual art the idea or concept is the most important aspect of the work ... [A]ll of the planning and decisions are made beforehand and the execution is a perfunctory affair. The idea becomes a machine that makes the art." LeWitt observed "This kind of art ... is usually free from the dependence on the skill of the artist as a craftsman." In LeWitt's case, this freedom 
was often accomplished by having his work executed by someone else. Of his trademark wall drawings, he wrote: "The artist conceives and plans the wall drawing. It is realized by draftsmen." ${ }^{27}$ LeWitt made no stipulation that the artist must approve the executed drawing, and he often does not see the completed works done from his plans. The Pop artist Andy Warhol's paintings were made by applying images to canvas through a silk screen. "The silk-screens are made from photographs taken by someone else, and the screening is often done by someone else in Warhol's factory, so that the artist's part can be isolated as the choice of images and the decision to repeat the image and perhaps to magnify it." ${ }^{28}$ The procedure was a direct consequence of Warhol's philosophy: "The reason I'm painting this way is that I want to be a machine." 29 Another successful Pop painter of the "60s, Roy Lichtenstein, did execute his paintings by hand, but in such a way that it would appear otherwise: "I want my painting to look as if it had been programmed. I want to hide the record of my hand." 30

For these and other artists in the second cohort, the ideas represented by their work became the work's focal point: as one critic wrote of LeWitt, their procedures "made the initial intention more important than the execution." ${ }^{31}$ The deemphasis of craftsmanship, and the growing role of conceptual innovation, made painting progressively less like the disciplines described by the psychologists as concrete, and more like those they consider to be abstract: whereas the achievements of the Abstract Expressionists rested on techniques developed over extended periods, the most celebrated accomplishments of the later cohort were primarily ideational, with technique relegated to a minor role, if any. An implication of this change is that for producing work of high quality, the value of experience in the profession should have been reduced, as painting should have become one of the disciplines in which significant contributions 
are typically made by the young. ${ }^{32}$ This analysis of the American market for contemporary art therefore leads to the prediction that successful artists coming of age in the 1950s and '60s - those of the second cohort considered here - should have executed their best work at ages younger than those at which members of the first cohort had produced theirs. This is the hypothesis to be tested below.

\section{Data and Econometric Analysis}

The data analyzed in this paper are drawn from auctions held during 1980-96. The source of these data is the annual editions of Le Guide Mayer, which complies the results of fine art auctions held all over the world.$^{33}$ Mayer classifies the works sold into five groups: prints, drawings, watercolors, paintings, and sculptures. This study collected the records of all sales of paintings and watercolors by the 51 artists listed in Table 1 from the 17 annual editions of Mayer for auctions held during 1980-96. This yielded a total of 4,395 sales of individual works. Most of these sales occurred in the United States, and nearly 90\% were sold by the two leading auction houses, Sotheby's and Christie's. For each painting in the data set, the coding for this study recorded the support (paper or canvas), size, date of execution, date sold, and sale price. ${ }^{34}$

Table 1 presents summary statistics for these data. Just over one quarter of the paintings 1,109 - were done by artists born during 1900-20, while 3,286 were painted by artists born during 1921-40. The mean age of the artists of the first cohort when their paintings were produced was 51, while the mean for the second cohort was 42 . The youngest age observed in the sample is for Jackson Pollock, who was 19 when he produced a painting included here, while the oldest, of 79, is for Agnes Martin. Works by members of the first cohort sold on average for twice as much as 
those by the second cohort - $\$ 230,000$ for the first cohort as opposed to $\$ 115,000$ for the second (in 1983 dollars).

Our interest is in comparing across cohorts the relationship between the price of a painting and the artist's age at the date of its execution. We do this by estimating a regression in which the price of a painting is expressed as a polynomial in the age of the artist, interacted with whether the artist was born after 1920. A number of other variables are also included in the regression. In view of the large differences in the value of works by different artists, we include fixed effects for individual artists. There were substantial fluctuations in the art market during the years from which our data are drawn, so our regressions include binary variables for the year of sale. A binary independent variable was included to indicate whether a work was done on paper or canvas, and the size of the work was controlled using the natural logarithm of the surface area.

Formally, our specification is given by

$$
\begin{aligned}
& \ln \left(\text { Price }_{\mathrm{ij}}=\beta_{1} \text { Pre }_{\mathrm{i}} \text { Age }_{\mathrm{ij}}+\beta_{2} \text { Pre }_{\mathrm{i}} \text { Age }_{\mathrm{ij}}{ }^{2}+\beta_{3} \operatorname{Pre}_{\mathrm{i}} \text { Age }_{\mathrm{ij}}{ }^{3}+\beta_{4} \text { Pre }_{\mathrm{i}} \text { Age }_{\mathrm{ij}}{ }^{4}\right. \\
& +\gamma_{1} \text { Post }_{\mathrm{i}} \text { Age }_{\mathrm{ij}}+\gamma_{2} \text { Post }_{\mathrm{i}} \text { Age }_{\mathrm{ij}}{ }^{2}+\gamma_{3} \text { Post }_{\mathrm{i}} \text { Age }_{\mathrm{ij}}{ }^{3}+\gamma_{3} \text { Post }_{\mathrm{i}} \text { Age }_{\mathrm{ij}}{ }^{4} \\
& +\phi_{1} \text { Paper }_{\mathrm{ij}}+\phi_{\mathrm{ij}} \ln \left(\text { Area }_{\mathrm{ij}}+\Sigma_{\mathrm{k}=1}^{51} \psi_{\mathrm{k}} \mathrm{I}(\mathrm{i}=\mathrm{k})\right. \\
& \left.+\Sigma \underset{\mathrm{y}=80}{96} \theta_{\mathrm{y}} \text { I }_{\left(\text {Saleyear }_{\mathrm{ij}}\right.}=\mathrm{y}\right)+\varepsilon_{\mathrm{ij}}
\end{aligned}
$$

where $A g e_{i j}$ denotes the age of artist $i$ when his $j$ th painting was executed; Pre $e_{i}$ is a binary variable equal to 1 if the artist was born during 1900-20; Post $t_{i}$ is a binary variable equal to 1 if the artist was born during 1921-40; $\psi_{\mathrm{k}}$ denotes a set of dummy variables for individual artists [(I(i=k) is an indicator function equal to 1 if $\mathrm{i}=\mathrm{k}]$; and $I\left(\right.$ Saleyear $\left._{i j}=y\right)$ is an indicator function equal to 1 if painting $i j$ was sold in year $y$. 
Several remarks are in order. First, the results presented below are based on a fourthdegree polynomial in the artist's age. The choice of degree was based on a test for the significance of higher-order terms. ${ }^{35}$ The results are similar, however, when the age-price profiles are estimated using either a third - or fifth-order polynomial. Second, to account for differences in the variability of different artists' sale prices, each artist's paintings are weighted by the inverse of the mean square error for that artist. The number of observations varies across artists. Treating each painting as an observation implicitly weights artists with more sales more heavily than those with fewer sales. ${ }^{36}$ Third, the model presented above does not include controls for the year a painting was produced. To allow for the possibility of vintage effects, we reestimated the equation with such controls.

The regression estimates are presented in Table 3. Figure 1 plots the age-price profiles for each cohort, from the estimates of the first column. For the first cohort, prices increase from age 20 to the early 50s before declining; the implied peak is at 50.6 years. As predicted above, prices peak considerably earlier for the second cohort. The implied maximum is at 28.8 years. Thus whereas artists born through 1920 tended to produce their most valuable work late in their careers, artists born after that date typically executed their most valuable work within the first decade of their careers.

We test for differences in the age-price relationships in two ways. First we test for the equality of the age-price profiles. The F-statistic for the equality of the two age profiles in column 1 is 72.6, with 4 and 4,368 degrees of freedom in the numerator and denominator, respectively, compared to a critical value of 2.38 at the $5 \%$ level. Our main interest, however, is in comparing the peak ages across cohorts. The estimated ages of peak value differ by 21.8 years. To test for 
the equality of the peak ages, standard errors for the peaks were constructed using the delta method. The standard errors for the peak ages are .815 and 1.105 for the first and second cohorts, respectively, while the standard error for the difference is 1.37 . The t-statistic for the equality of the peaks is 15.9 .

Inclusion of the vintage effects has little effect on the age-price profiles, as shown in column 2 of Table 3. The peak age of the first cohort declines slightly, to 49.9 years, while the peak of the second cohort increases to 31.2. The difference in the peak ages remains highly statistically significant.

\section{Market Values and Critical Evaluation}

The art market is often dismissed by scholars and critics as having little relevance to art appreciation. This has been particularly common for contemporary art: in 1962, in a well-known remark, one critic complained that the new art was attracting a new clientele, and that art galleries were being invaded by "gum chewers, bobby soxers, and worse, delinquents." ${ }^{37}$ A salient question consequently concerns whether auction prices for contemporary art reflect sophisticated critical judgments. ${ }^{38}$

Implicit evidence of scholars' judgments of the timing of the most important stage of an artist's career can be drawn from the reproductions contained in books about contemporary art. These reproductions are chosen to illustrate each artist's most important contribution. Without assuming any single judgment to be definitive, considering a number of books can provide a survey of informed critical opinion.

Table 4 is based on a tabulation of illustrations contained in 26 books, published since 
1980, that analyze contemporary painting. For each of 20 painters, the table shows the total number of illustrations of that artist's work contained in the 26 books, the median date of execution of the paintings represented by those illustrations, and the artist's age at that date. The 20 artists selected comprise the 10 painters from each of the cohorts considered here who had the greatest number of paintings sold at auction during 1980-96; the 10 from the first cohort account for $89 \%$ of the paintings in the sample done by members of their cohort, while the 10 from the second cohort account for $59 \%$ of all paintings in the sample done by members of theirs.

Table 4 shows a clear difference between the two cohorts. For 9 of the 10 artists in the first cohort, the median painting illustrated was done when the artist was above the age of 40; for two it was done above the age of 50. In contrast, only one of the 10 artists in the second cohort executed his median painting above the age of 40 , and three painted it while still in their $20 \mathrm{~s}$. The mean of the ages in Table 4 falls from 45.4 for the artists of the first cohort to 33.9 for those of the second. Table 4 thus demonstrates clearly that scholars agree with the result obtained above from the auction market, that the age at which successful modern American painters typically did their best work declined sharply between the two cohorts considered by this study.

\section{$\underline{\text { Conclusion }}$}

When Frank Stella was given a retrospective exhibit at New York’s Museum of Modern Art in 1970, at the age of just 33, the critic Harold Rosenberg remarked acidly that "The young master is a new phenomenon in American art." Rosenberg declared flatly that "It is inconceivable that Cézanne, Matisse, or Miró could have qualified for a retrospective in a leading museum after their first dozen years of painting; certainly Gorky, Hofmann, Pollock, and de Kooning did not." 
Rosenberg argued that "For a coherent body of significant paintings to spring directly out of an artist's early thoughts, a new intellectual order had to be instituted in American art." 39

Although Rosenberg deplored this situation, his analysis of it was correct, and it is precisely this new intellectual order that underlies the econometric results obtained in this paper. The sudden increase in the demand for contemporary American art during the 1950s, with the increased premium it placed on innovation, transformed the nature of American painting. As the experimental methods of the Abstract Expressionists were replaced by a variety of conceptual approaches, and the expressive gestures of Pollock, de Kooning, and their contemporaries gave way to the mechanical and geometric productions of Warhol, Stella, and others, the value of experience to painters declined sharply, and the age at which successful artists produced their best work declined precipitously. Modern American painting consequently offers a striking case study of a profession in which a shift in demand produced a sudden and radical change in the careers of successful practitioners. 
$\underline{\text { Endnotes }}$

For discussions and comments we thank Fernando Alvarez, Orley Ashenfelter, Gary Becker, Tim Conley, Lance Davis, Stanley Engerman, Allison Gamble, Charles Gray, John James, Randy Kroszner, Gracie Mansion, Thomas Sargent, Dean Keith Simonton, Lester Telser, Robert Topel, David Weir, and an anonymous referee. Thomas Walker and Sean Buckley provided excellent research assistance.

1. Harvey C. Lehman, Age and Achievement (Princeton: Princeton University Press, 1953), pp. 324-25; Dean Keith Simonton, Scientific Genius: A Psychology of Science (Cambridge: Cambridge University Press, 1988), p. 67; Simonton, Greatness: Who Makes History and Why (New York: Guilford Press, 1994), pp. 185-88.

2. Simonton, Scientific Genius, pp. 68-75.

3. $\quad$ E.g. see Lehman, Age, pp. 289-307.

4. Ann P. Bartel and Nachum Sicherman, "Technological Change and the Retirement Decisions of Older Workers," Journal of Labor Economics, Vol. 11, No. 1 (January 1993), pp. 162-83; also see Yoram Ben-Porath, "The Production of Human Capital and the Life Cycle of Earnings," Journal of Political Economy, Vol. 75, No. 4 (August 1967), pp. 352-65, and Ann P. Bartel and Nachum Sicherman, "Technological Change and the Skill Acquisition of Young Workers," Working paper 5107, National Bureau of Economic Research (1995).

5. The books are: George Heard Hamilton, $19^{\text {th }}$ and $20^{\text {th }}$ Century Art (New York: Abrams, 1970); John Russell, The Meanings of Modern Art (New York: Museum of Modern Art, 1974); H. H. Arnason, History of Modern Art, Third ed. (New York: Abrams, 1986); Robert Hughes, The Shock of the New (New York: Knopf, 1982); Daniel Wheeler, Art Since Mid-Century, 1945 to the Present (Englewood Cliffs, NJ: Prentice-Hall, 1991); Sam Hunter and John Jacobus, History of Modern Art, Third ed. (Englewood Cliffs, NJ: Prentice-Hall, 1992).

6. Adolph Gottlieb, "The Artist and the Public," Art in America, Vol. 42, No. 4 (December 1954), p. 267.

7. $\quad$ E. A. Carmean and Eliza E. Rathbone, American Art at Mid-Century (Washington, D.C.: National Gallery of Art, 1978), p. 15.

8. Harold Rosenberg, The Tradition of the New (New York: Horizon Press, 1960), p. 25.

9. B. H. Friedman, Jackson Pollock (New York: McGraw-Hill, 1972), p. 176. 
10. Irving Sandler, The Triumph of America Painting (New York: Praeger, 1970); Dore Ashton, The New York School (Berkeley: University of California Press, 1992); Stephanie Terenzio, ed., The Collected Writings of Robert Motherwell (New York: Oxford University Press, 1992), pp. 76-84, 254-58; Stephen Polcari, Abstract Expressionism and the Modern Experience (Cambridge: Cambridge University Press, 1991); Michael Leja, Reframing Abstract Expressionism (New Haven: Yale University Press, 1993).

11. Clement Greenberg, The Collected Essays and Criticism, Vol. 2 (Chicago: University of Chicago Press, 1986), p. 287; Greenberg, Collected Essays, Vol. 3 (Chicago: University of Chicago Press, 1993), p. 321.

12. Ashton, New York School, pp. 157-61; Barbara M. Reise, "Greenberg and the Group: A Retrospective View," in Francis Frascina and Jonathan Harris, eds., Art in Modern Culture (London: Phaideon, 1992), pp. 252-63; Paul Wood, et. al., Modernism in Dispute (Yale: Yale University Press, 1993), pp. 42-65; Florence Rubenfeld, Clement Greenberg (New York: Scribner, 1997), pp. 100-14.

13. Ashton, New York School, pp. 164-73; Henry Geldzahler, Making It New (San Diego: Harcourt Brace, 1996), pp. 114-17.

14. William S. Rubin, Frank Stella (New York: Museum of Modern Art, 1970), p. 41.

15. Ashton, New York School, p. 128.

16. Greenberg, Collected Essays, Vol. 2, p. 189.

17. Peter Fuller, "American Painting Since the Last War," in David Shapiro and Cecile Shapiro, eds., Abstract Expressionism (Cambridge: Cambridge University Press, 1990), p. 178.

18. Michael Fried, Three American Painters (Cambridge, MA: Fogg Art Museum, 1965), p. 8.

19. Leo Steinberg, Other Criteria (London: Oxford University Press, 1972), pp. 77-8.

20. Henry Geldzahler, New York Painting and Sculpture: 1940-1970 (New York: E. P. Dutton, 1969), pp. 28-29.

21. Emile de Antonio and Mitch Tuchman, Painters Painting (New York: Abbeville Press, 1984), p. 79.

22. Greenberg, Collected Essays and Criticism, Vol. 4 (Chicago: University of Chicago Press, 1993), p. 300.

23. Geldzahler, New York Painting, p. 28. 
24. Michael Fried, Art and Objecthood (Chicago: University of Chicago Press, 1998), p. 3.

25. Ibid., p. 24.

26. Kristine Stiles and Peter Selz, Theories and Documents of Contemporary Art (Berkeley: University of California Press, 1996), p. 121.

27. Adachiara Zevi, ed., Sol LeWitt: Critical Texts (Rome: Inonia, 1994), pp. 78, 95.

28. Steven Henry Madoff, ed., Pop Art (Berkeley: University of California Press, 1997), p. 291.

29. Ibid., p. 104.

30. $\quad$ Ibid., p. 198.

31. Zevi, Sol LeWitt, p. 293; also see Johanna Drucker, Theorizing Modernism (New York: Columbia University Press, 1994), p. 91.

32. Simonton, Scientific Genius, p. 73.

33. Le Guide Mayer (Lausanne: Sylvio Acatos, annual).

34. The sale price given by Mayer is the hammer price, i.e. it includes the commission charged by the auctioneer to the seller, but not the premium charged to the buyer. See Orley Ashenfelter, "How Auctions Work for Wine and Art," Journal of Economic Perspectives, Vol. 3, No. 3 (Summer 1989), pp. 23-36, for a discussion of auction practices.

35. The fourth-order polynomial was chosen by including fifth-order terms in age and testing for their joint significance. The p-value for the F-test that the fifth-order terms were 0 was .076. An F-test of the hypothesis that the fourth-order terms were 0 yielded a p-value beneath .0001 .

36. The results are similar when each painting is weighted by the inverse of the number of paintings by that artist so that each artist receives equal weight.

37. Madoff, Pop Art, p. 32.

38. Use of critical evaluations can also dispel sample selection issues. Auction prices are available only for privately held paintings; once paintings enter a museum collection, they rarely return to the auction market. In many cases, an artist's most important works are owned by museums, and are consequently not reflected in one age-price profiles. If museums acquire artists' best works our age-price profiles will be flattened. Critical evaluations can provide another source of information, immune to this selection, with which to check our estimates. 
39. Harold Rosenberg, The De-definition of Art (Chicago: University of Chicago Press, 1983), pp. 130-31. 
Table 1: Artists Included in this Study

\begin{tabular}{|c|c|c|c|}
\hline Artists Born 1900-20 & Country of birth & Year of birth & Year of death \\
\hline Gorky, Arshile & Armenia & 1904 & 1948 \\
\hline Gottlieb, Adolph & US & 1903 & 1974 \\
\hline Guston, Philip & Canada & 1913 & 1980 \\
\hline Kline, Franz & US & 1910 & 1962 \\
\hline de Kooning, Willem & Holland & 1904 & 1997 \\
\hline Louis, Morris & US & 1912 & 1962 \\
\hline Martin, Agnes & US & 1912 & \\
\hline Motherwell, Robert & US & 1915 & 1991 \\
\hline Neel, Alice & US & 1900 & 1984 \\
\hline Newman, Barnett & US & 1905 & 1970 \\
\hline Pollock, Jackson & US & 1912 & 1956 \\
\hline Porter, Fairfield & US & 1907 & 1975 \\
\hline Reinhardt, Ad & US & 1913 & 1967 \\
\hline Rothko, Mark & Russia & 1903 & 1970 \\
\hline Still, Clyfford & US & 1904 & 1980 \\
\hline Artists Born 1921-40 & Country of birth & Year of birth & Year of death \\
\hline Anuszkiewicz, Richard & US & 1930 & \\
\hline Close, Chuck & US & 1940 & \\
\hline Diebenkorn, Richard & US & 1922 & 1993 \\
\hline Dine, Jim & US & 1935 & \\
\hline Estes, Richard & US & 1936 & \\
\hline Flack, Audrey & US & 1931 & \\
\hline Francis, Sam & US & 1923 & 1994 \\
\hline Frankenthaler, Helen & US & 1928 & \\
\hline
\end{tabular}




\begin{tabular}{|l|c|c|l|}
\hline Hockney, David & Great Britan & 1937 & \\
\hline Indiana, Robert & US & 1928 & \\
\hline Johns, Jasper & US & 1930 & \\
\hline Kelly, Ellsworth & US & 1923 & \\
\hline Kitaj, Ronald & US & 1932 & \\
\hline LeWitt, Sol & US & 1928 & \\
\hline Lichtenstein, Roy & US & 1923 & 1997 \\
\hline Mangold, Robert & US & 1937 & \\
\hline Marden, Brice & US & 1938 & \\
\hline Mitchell, Joan & US & 1926 & 1992 \\
\hline Morley, Malcolm & Great Britan & 1931 & \\
\hline Moskowitz, Robert & US & 1935 & \\
\hline Murray, Elizabeth & US & 1940 & \\
\hline Noland, Kenneth & US & 1924 & \\
\hline Olitski, Jules & Russia & 1922 & \\
\hline Pearlstein, Philip & US & 1924 & \\
\hline Poons, Larry & Japan & 1937 & \\
\hline Rauschenberg, Robert & US & 1925 & \\
\hline Rivers, Larry & US & 1923 & \\
\hline Rockburne, Dorothea & US & 1934 & \\
\hline Rosenquist, James & US & 1933 & \\
\hline Ruscha, Ed & US & 1937 & \\
\hline Ryman, Robert & 19287 \\
\hline Stella, Frank & US & 1926 & \\
\hline Twombly, Cy & US & \\
\hline Warhol, Andy & US & \\
\hline Wesselman, Tom & US & \\
\hline Youngerman, Jack & US & \\
\hline
\end{tabular}


Table 2: Summary Statistics

\begin{tabular}{|l|c|c|c|c|c|c|}
\hline \multicolumn{9}{|c|}{ All } & Pre-1920 Cohort & \multicolumn{2}{c|}{ Post- 1920 Cohort } \\
\hline Variable & Mean & Std. Dev. & Mean & Std. Dev. & Mean & Std. Dev. \\
\hline Year of Birth & 1923 & 10 & 1908 & 4.6 & 1928 & 5.0 \\
\hline Year of Execution & 1968 & 10.9 & 1959 & 11.3 & 1971 & 9.1 \\
\hline Age at Execution & 44.5 & 10.8 & 50.9 & 11.7 & 42.3 & 9.5 \\
\hline Year of Sale & 1989 & 4.7 & 1988 & 4.7 & 1989 & 4.7 \\
\hline $\begin{array}{l}\text { Price (in 1983 } \\
\text { Dollars) }\end{array}$ & 143,965 & 522,415 & 230,170 & 733,070 & 114,872 & 424,783 \\
\hline $\begin{array}{l}\text { Area (in square } \\
\text { inches) }\end{array}$ & 2593 & 4116 & 2226 & 3166 & 2717 & 4384 \\
\hline Paper & .291 & .454 & .344 & .475 & .273 & .446 \\
\hline Observations & 4395 & & & & 3286 \\
\hline
\end{tabular}


Table 3: Determinants of Sale Prices.

Pre-1920*Age

Pre-1920*Age ${ }^{2}$

Pre-1920*Age ${ }^{3}$

$-.000476$

$(.000125)$

Pre-1920*Age ${ }^{4}$

.00000263

$(.00000063)$

Pre-1920*Age

.816

Pre-1920*Age ${ }^{2}$

Pre-1920*Age ${ }^{3}$

.000356

$(.000164)$

Pre-1920*Age ${ }^{4}$

$-.00000172$

(.00000093)

Log Surface Area

.564

$(.011)$

Paper

$-.553$

$(.034)$

Dummy Variables for Year of Sale

Yes

$\mathrm{R}^{2}$

.6271

Number of Observations

4395

Dependent variable is log of sale price. Standard errors in parentheses. Regressions weighted by the inverse of the mean square error for each artist to control for inter-artist differences in the variability of sales prices.

Note. Deviation of log sale price from cohort mean calculated from a quartic in age when painting was executed interacted with birth of artist pre- / post-1920 controlling for artist fixed effects, fixed effects for year of sale, surface 
Table 4: Ages from which Artists' Work is Illustrated in Selected Books

\begin{tabular}{|c|c|c|c|}
\hline Born 1900-20 & Total illustrations & $\begin{array}{c}\text { Median year of } \\
\text { illustrations }\end{array}$ & $\begin{array}{c}\text { Age of artist in } \\
\text { median year }\end{array}$ \\
\hline Gottlieb, Adolph & 12 & 1949 & 46 \\
\hline Guston, Philip & 25 & 1956 & 43 \\
\hline Kline, Franz & 21 & 1952 & 42 \\
\hline de Kooning, Willem & 48 & 1952 & 48 \\
\hline Louis, Morris & 24 & 1960 & 48 \\
\hline Martin, Agnes & 8 & 1965 & 53 \\
\hline Motherwell, Robert & 21 & 1960 & 45 \\
\hline Pollock, Jackson & 80 & 1948 & 36 \\
\hline Reinhardt, Ad & 13 & 1955 & 42 \\
\hline Rothko, Mark & 57 & 1954 & 51 \\
\hline \multicolumn{4}{|l|}{ Born 1921-40 } \\
\hline Dine, Jim & 7 & 1963 & 28 \\
\hline Francis, Sam & 7 & 1958 & 35 \\
\hline Frankenthaler, Helen & 21 & 1953 & 25 \\
\hline Lichtenstein, Roy & 39 & 1963 & 40 \\
\hline Noland, Kenneth & 23 & 1964 & 40 \\
\hline Rauschenberg, Robert & 40 & 1959 & 34 \\
\hline Stella, Frank & 32 & 1964 & 28 \\
\hline Twombly, Cy & 4 & 1969 & 41 \\
\hline Warhol, Andy & 48 & 1963 & 35 \\
\hline Wesselman, Tom & 9 & 1964 & 33 \\
\hline
\end{tabular}

Source: The books surveyed for this table, by date of publication, are the following: 
Norbert Lynton, The Story of Modern Art (Ithaca: Cornell University Press, 1980).

John Russell, The Meanings of Modern Art (New York: Museum of Modern Art, 1981).

Dore Ashton, American Art Since 1945 (New York: Oxford University Press, 1982).

Hugh Honour and John Fleming, A World History of Art (London: Macmillan, 1982).

Robert Hughes, The Shock of the New (New York: Alfred Knopf, 1982).

Sara Cornell, Art: A History of Changing Style (Englewood Cliffs, NJ: Prentice-Hall, 1983).

Ralph A. Britsch and Todd A. Britsch, The Arts in Western Culture (Englewood Cliffs, NJ: Prentice-Hall, 1984).

E. H. Gombrich, The Story of Art, Fourteenth ed. (Englewood Cliffs, NJ: Prentice-Hall, 1985).

H. H. Arnason, History of Modern Art, Third ed. (New York: Harry Abrams, 1986).

Frederick Hartt, Art, Vol. 2, Third ed. (Englewood Cliffs, NJ: Prentice-Hall, 1989).

Michael Wood, Bruce Cole, and Adelheid Gealt, Art of the Western World (New York: Simon \& Schuster, 1989).

David Anfam, Abstract Expressionism (London: Thames and Hudson, 1990).

Daniel Wheeler, Art Since Mid-Century (Englewood Cliffs, NJ: Prentice-Hall, 1991).

Sam Hunter and John Jacobus, Modern Art, Third ed. (Englewood Cliffs, NJ: Prentice-Hall, 1992).

Carol Strickland and John Boswell, The Annotated Mona Lisa (Kansas City: Andrews and McMeel, 1992).

Paul Wood, Francis Frascina, Jonathan Harris, and Charles Harrison, Modernism in Dispute (New Haven: Yale University Press, 1993).

Laurie Schneider Adams, A History of Western Art (New York: Harry Abrams, 1994).

Nikos Stangos, ed., Concepts of Modern Art (London: Thames and Hudson, 1994).

Marilyn Stokstad, Art History (New York: Harry Abrams, 1994).

Edward Lucie-Smith, Movements in Art Since 1945, Third ed. (London: Thames and Hudson, 1995).

Liz Dawtrey, Toby Jackson, Mary Masterson, Pam Meecham, and Paul Wood, Investigating Modern Art (New Haven: Yale University Press, 1996).

Charles Harrison, Modernism (Cambridge: Cambridge University Press, 1997).

David G. Wilkins, Bernard Schultz, and Katheryn M. Linduff, Art Past, Art Present, Third ed. (NewYork: Harry Abrams, 1997).

Alison Gallup, Gerhard Gruitrooy, and Elizabeth M. Weisberg, Great Paintings of the Western World (New York: Hugh Lauter Levin Associates, 1987).

John Freeman, Art (New York: Watson-Guptill, 1998).

Volker Gebhardt, The History of Art (New York: Barron's Educational Series, 1998). 

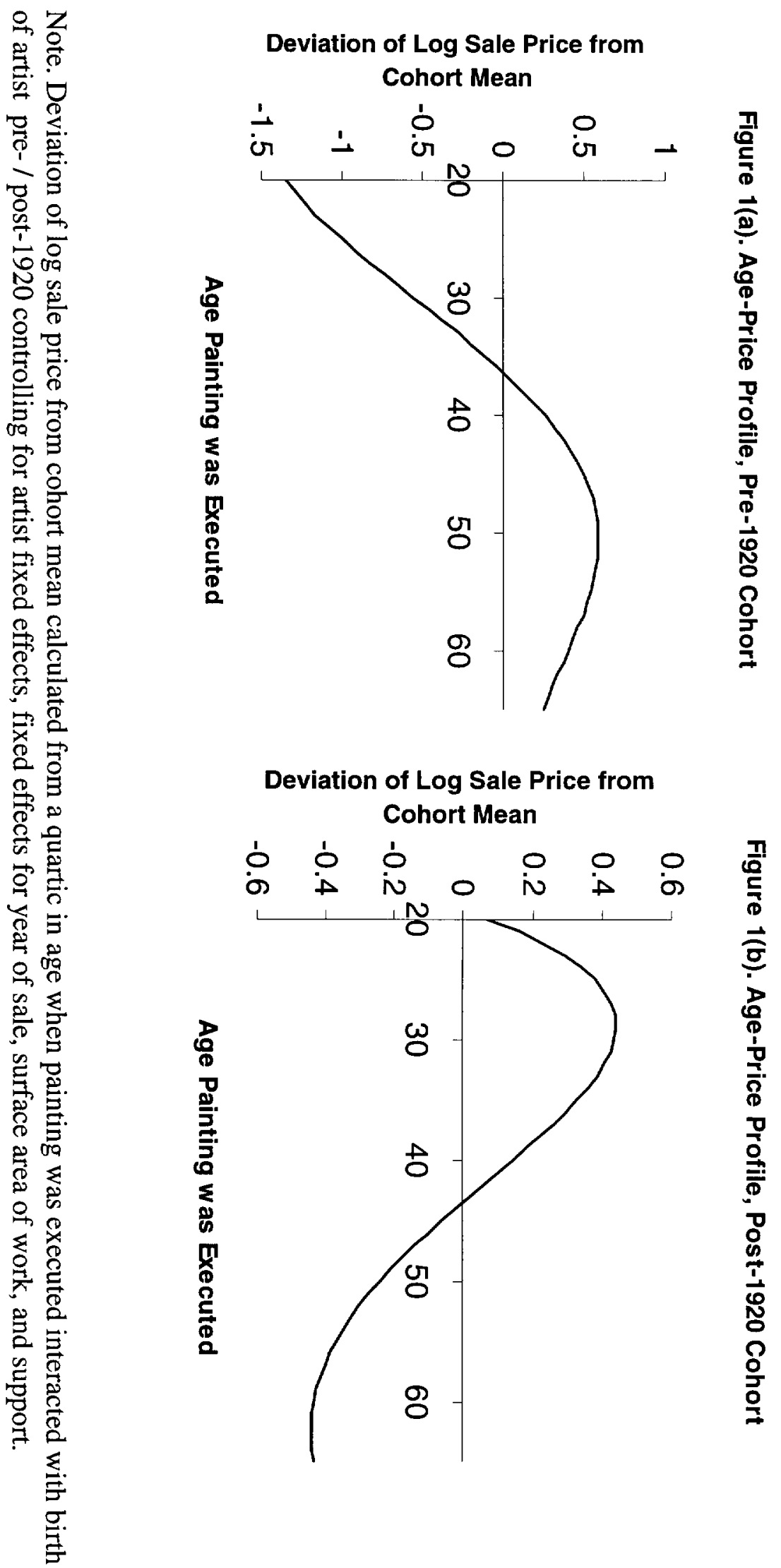